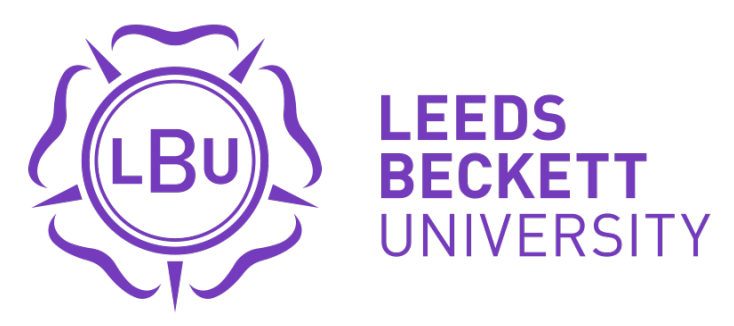

Citation:

Senior, AM (2014) Relics of bioart: Ethics and messianic aesthetics in performance documentation. Theatre Journal, 66 (2). 183 - 205. ISSN 0192-2882 DOI: https://doi.org/10.1353/tj.2014.0046

Link to Leeds Beckett Repository record:

https://eprints.leedsbeckett.ac.uk/id/eprint/2512/

Document Version:

Article (Published Version)

The aim of the Leeds Beckett Repository is to provide open access to our research, as required by funder policies and permitted by publishers and copyright law.

The Leeds Beckett repository holds a wide range of publications, each of which has been checked for copyright and the relevant embargo period has been applied by the Research Services team.

We operate on a standard take-down policy. If you are the author or publisher of an output and you would like it removed from the repository, please contact us and we will investigate on a case-by-case basis.

Each thesis in the repository has been cleared where necessary by the author for third party copyright. If you would like a thesis to be removed from the repository or believe there is an issue with copyright, please contact us on openaccess@leedsbeckett.ac.uk and we will investigate on a case-by-case basis. 


\section{PROJECT MUSE}

Relics of Bioart: Ethics and Messianic Aesthetics in Performance Documentation

Adele Senior

Theatre Journal, Volume 66, Number 2, May 2014, pp. 183-205 (Article)

Published by Johns Hopkins University Press

DOI: $10.1353 / t$.2014.0046

$\Rightarrow$ For additional information about this article

http://muse.jhu.edu/journals/tj/summary/v066/66.2.senior.html 


\title{
Relics of Bioart: Ethics and Messianic Aesthetics in Performance Documentation
}

\author{
Adele Senior
}

When Australia-based artists Oron Catts and Ionat Zurr collaborated with performance artist Stelarc on Extra Ear $1 / 4$ Scale (2003), they could not have predicted that, just weeks before the opening, the National Gallery of Victoria (NGV) would cancel the installation on account of its proposed use of human tissue. Catts and Zurr, who are also known as the art collective Tissue Culture and Art Project (TC\&A), have been using tissue technologies as artistic media since 1996 and continue to work in this field today. ${ }^{1}$ For the artists, employing living/biological materials is a necessary hands-on means of "confront[ing] broader cultural perceptions of 'life' given our increasing ability to manipulate living systems." ${ }^{2}$ To explore this increasing ability to manipulate life, Catts and Zurr draw on the knowledge and tools of tissue engineering, "an interdisciplinary field that applies the principles of engineering and life sciences towards the development of biological substitutes that restore, maintain, or improve tissue function or a whole organ." ${ }^{3}$ In particular, the artists use tissue-culture techniques to grow cells and tissue in vitro over biodegradable scaffolds that have been shaped by the artists into different cultural artifacts like dolls, wings, and ears. In the case of Extra Ear, they created a scaled-down, artificial sculpture of one of Stelarc's ears and grew human tissue around it to explore the evocative potential of "partial life" that is cultivated outside of the body using the tools of biotechnology. The gallery was troubled by this use of human tissue, despite the fact that the installation had already gained ethical, safety, and health clearances from the University of Western Australia, where Catts and Zurr are long-term residents. When the gallery asked for a statement from the artists claiming that the piece would not raise "ethical issues," Catts and Zurr refused to provide this placation on the basis that their work is fundamentally concerned with provoking ethical questions. ${ }^{4}$ In response to the artists' refusal to provide the statement, the NGV

Adele Senior is a lecturer in drama at the University of Exeter. She has been interested in the biological arts since 2004, has written a PhD on the subject, and undertaken a research residency at SymbioticA, the art and science collaborative research laboratory at the University of Western Australia. Her other research interests include animals in theatre; performance documentation and notions of the archive; and the potential of Derridean deconstruction for analyzing performance and live art practices.

\footnotetext{
${ }^{1}$ Between 1999 and 2003, TC\&A also worked with artist and researcher Guy Ben-Ary.

${ }^{2}$ Oron Catts and Ionat Zurr, "The Art of the Semi-Living and Partial Life: Extra Ear-1/4 Scale" (n.d.), available at http://www.tca.uwa.edu.au/publication/TheArtoftheSemi-LivingandPartialLife.pdf (accessed 17 September 2013).

${ }^{3}$ Robert Langer and Joseph P. Vacanti, “Tissue Engineering," Science 260, no. 5110 (1993): 290.

${ }^{4}$ Catts and Zurr, "The Art of the Semi-Living and Partial Life," 9.
} 
cancelled the installation and then later allowed it go ahead on the condition that the artists did not use human tissue. Consequently, Catts and Zurr used animal tissue. ${ }^{5}$

A decade has now passed since the attempted censorship of Extra Ear on the basis of its anticipated "ethical" reception, and yet the specific ethical dimensions of TC\&A's work have still to be fully explored, beyond the artists' own commentary on their work. ${ }^{6}$ A critical reading of ethics in the spectatorial encounter with TC\&A's work is particularly important when ethics are invoked by a gallery to make a political decision about whether or not a piece of work will be shown in public. There are some notable scholarly attempts within the field of performance that discuss, or call for a critique of, ethics in bioart, but these accounts are predominantly concerned with the ethics of producing bioart, rather than theorizing an ethics of its reception. ${ }^{7}$ Bioart here refers to a broad range of artistic practices that employ living/biological materials and bio(techno) logical tools as media and/or subject matter. Recent scholarship on bioart practices has dealt with some of the more detailed aspects of spectatorial experience, but does not address the dimensions of encountering bioart in specifically ethical terms. ${ }^{8}$ This essay examines the ethics of spectatorship in TC\&A's work by arguing three main points: first, that it references, plays with, and is haunted by religious iconography; second, that addressing its messianic resonances illuminates an ethics of spectatorship that is closely related to a Derridean ethical experience of otherness; and last, that focusing on TC\&A's documentary images sheds light on the potential of bioart documentation to generate affect and relations of an ethical nature. I argue that this potential has been overlooked by previous attempts to valorize or privilege the live event. ${ }^{9}$

Performance scholarship on the animal offers a useful starting point for thinking about the ethics of encountering living or biological materials in art and performance practice. ${ }^{10}$ The field raises illuminating ethical and political issues relating to consent,

\footnotetext{
${ }^{5}$ Ibid., 9-10.

${ }^{6}$ Ionat Zurr and Oron Catts, "The Ethical Claims of Bioart: Killing the Other or Self-Cannibalism" (2003), available at www.tca.uwa.edu.au/publication/TheEthicalClaimsofBioart.pdf (accessed 17 September 2013).

${ }^{7}$ Susan Broadhurst, "Bioart: Transgenic Art and Recombinant Theatre," Body, Space and Technology 5 (2005), available at http://people.brunel.ac.uk/bst/vol05/index.html (accessed 17 September 2013); Broadhurst, Digital Practices: Aesthetic and Neuroesthetic Approaches to Performance and Technology (Basingstoke, UK: Palgrave Macmillan, 2007); Matthew Causey, "The Ethics and Anxiety of Being with Monsters and Machines: Thinking Through the Transgenic Art of Eduardo Kac," Crossings: eJournal of Art and Technology 2, no. 1 (2002), available at http://www.ekac.org/Crossings.Vol.2.html (accessed 17 September 2013); Carol Gigliotti, "Leonardo's Choice: The Ethics of Artists Working with Genetic Technologies," AI and Society 20, no. 1 (2006): 22-34.

${ }^{8}$ Kelly Rafferty, "Regeneration: Tissue Engineering, Maintenance, and the Time of Performance," TDR: The Drama Review 56, no. 3 (2012): 82-99; Deborah Dixon, "Creating the Semi-Living: On Politics, Aesthetics and the More-than-Human," Transactions of the Institute of British Geographers 34 (2009): 411-25; Leon J. Hilton, “'The Horse in My Flesh': Transpecies Performance and Affective Athleticism," GLQ: A Journal of Lesbian and Gay Studies 19, no. 4 (2013): 487-514; Robert Mitchell, Bioart and the Vitality of Media (Seattle: University of Washington Press, 2010).

${ }^{9}$ See, for example, Jens Hauser, "Biotechnology as Mediality: Strategies of Organic Media Art," Performance Research 11, no. 4 (2006): 132; and Catts and Zurr, "The Art of the Semi-Living and Partial Life," 3.

${ }^{10}$ See, for example, Rachel Rosenthal, "Animals Love Theatre," TDR: The Drama Review 51, no. 1 (2007): 5-7; Jennifer Parker-Starbuck, "Becoming-Animate: On the Performed Limits of 'Human,'” Theatre Journal 58, no. 4 (2006): 649-68; Nicholas Ridout, "Animal Labour in the Theatrical Economy," Theatre Research International 1 (2004): 57-65; and Lourdes Orozco, Theatre and Animals (Basingstoke, UK: Palgrave Macmillan, 2013).
} 
exploitation, animal and human labor, and the potential for the animal to pose questions about human relations to otherness. In particular, animal scholarship in this area acknowledges an excessive phenomenality of the animal who/that is framed apart from everyday life, which can also be observed in some bioart practices. However, the primary focus on the whole animal means that the existing literature does not capture the specificity of the ethical relation between the human spectator and cells, tissues, and other forms of biological life that appear in bioart practices. ${ }^{11}$ Although scholarly concerns with the animal have contributed to challenging "the established assumption that the term 'performance' names an exclusively human-led and human-centered activity," ${ }^{\prime 2}$ the centrality of the animal body in these conversations marginalizes or excludes biological life beyond or outside of the body. How might performance studies address the ethical specificities of moving from what Rebecca Schneider terms the "body to body transmission" 13 of performance to body to partial life transmission in bioart?

In response to this question, I propose that attending to the play of religious iconography in TC\&A's work offers key insights into the kinds of ethical questions, demands, and concerns that are available to the spectator who encounters the "Semi-Living." I adopt this term Semi-Living from the artists who use it to describe the part-living, part-artificial sculptures that they grow using tissue technologies, and that require human intervention to provide nutrients and a sterile environment to keep the sculptures alive. Drawing on the documentary images of Pig Wings (2000-2002), Disembodied Cuisine (2003), and Tissue Culture and Art(ificial) Wombs (2000), I explore the connections between these images and artistic interpretations of the messianic events of the Nativity, the Last Supper, and the Shroud of Turin, respectively. These parallels with the birth, death, and resurrection of the Christian messiah, Jesus Christ, evoke what I refer to as a messianic aesthetic in their relationship to Christian iconography and illuminate the ethical relations between the spectator and the Semi-Living as other in TC\&A's work. By focusing on documentary images, I draw attention to their affective qualities and therefore take issue with interpretations of bioart that assume that the live event of performance offers an immediate and authentic encounter, as opposed to the "mediated" experience of documentation. ${ }^{14}$ Privileging or valorizing the live event underestimates the potential of bioart documentation to engage in affect and ethical relations. Writing on the vitality of media in bioart, Robert Mitchell further evidences this affect of documentation when he notes that "even simply learning that such a

\footnotetext{
${ }^{11}$ Parker-Starbuck identifies moments of "becoming-animate" in performance that "reveal the interrelationships and traces left between animal, human, and machine." Her thesis begins to recognize relations beyond the body. However, the examples are predominantly drawn from work featuring "complete" animal, human, or technological bodies. See "Becoming-Animate," 650. See also Jennifer Parker-Starbuck, "Animal Ontologies and Media Representations: Robotics, Puppets, and the Real of War Horse," Theatre Journal 65, no. 3 (2013): 373-93.

${ }^{12}$ Orozco, Theatre and Animals, 37.

${ }^{13}$ Schneider inherits this term from archivists Mary Edsall and Catherine Johnson, who used it to discuss the difficulty of preserving performance during a panel discussion at a Columbia University conference on "The Document" in 1997. Edsall and Johnson argue that history is lost in the "body to body transmission" of dance performance, while Schneider reclaims the term to discuss the ways in which memory does, in fact, remain in the body to body transmission of performances, such as oral storytelling, recitation, and ritual enactment. See Rebecca Schneider, "Archives: Performance Remains," Performance Research 6, no. 2 (2001): 101.

${ }^{14}$ See, for example, Hauser, "Biotechnology as Mediality," 132; and Catts and Zurr, "The Art of the Semi-Living and Partial Life," 3.
} 
project is 'out there somewhere' can produce a sort of adrenalized, excited concern (or crisis) on the part of some who read or hear about [it]." ${ }^{15}$ While Mitchell's claims about the affective experience of bioart are crucial to a critical engagement with bioart spectatorship in the gallery, his thesis can be extended to include documentation.

A key means of interrogating the ethical relations between the spectator and the Semi-Living is through Derrida's account of a "messianic without messianism."16 This is integral to a critical appreciation of ethics in TC\&A's work because it provides a vocabulary for an ethical experience of encountering the Semi-Living in the documentary images identified here. Derrida defines the idea of the messianic without messianism as a universal structure of experience that is open to "the coming of the other, the absolute and unpredictable singularity of the arrivant as justice." 17 Unlike the traditional messianisms of Christianity, Judaism, and Islam, Derrida's messianic without messianism is "without content and without [an] identifiable messiah." ${ }^{18}$ This version of the messianic is, therefore, open to the coming of the other who is not identified with a chosen people or a "religion of the book," to the exclusion of all others. For Adam Thurschwell, the messianic experience "leads to a conception of politics determined by an ethical demand for justice and responsibility to others," ${ }^{19}$ and articulates an ideal that Derrida refers to as "une démocratie à venir," or "a democracy to come." ${ }^{20} \mathrm{I}$ am not suggesting that TC\&A's work results in justice or democracy in the Derridean sense, but instead, by alluding to messianic events, these images are participating in the ethical gesture of being open to the other, an other of (as yet) unknowable characteristics who demands a response.

Like Derrida's messianic without messianism, TC\&A's images reference messianic events, but the messiah to which they allude is without content that would lead to a specific messianism. Thus, although the images draw on the Christian iconographic tradition, the other who calls for a response neither offers guidance nor answers from a determinable messianism. In other words, the spectator is not encouraged to draw on Christian morals and values to deal with the ethical challenges that are thrown up by this work. I argue, however, that it is precisely because of the undecidability of the Semi-Living other that the images play on the spectatorial urge to settle and fix meaning through recourse to a specific messianism. The Semi-Living other in Extra Ear was identified as human, and subsequently a moral calculation attributable to the Christian religion dominated the NGV's anticipated reception of the work, and has also been noted in other religious objections to the work. ${ }^{21}$ While outlining its grievances about Extra Ear in correspondence with the artists, the NGV continually referred to Andres Serrano's Piss Christ (1997), which is a photographic image of a crucifix submerged in what is supposedly the artist's urine. The photograph was displayed in an exhibition hosted by the NGV some years earlier and came under political attack from a

\footnotetext{
${ }^{15}$ Mitchell, Bioart and the Vitality of Media, 72.

${ }^{16}$ Jacques Derrida, Specters of Marx: The State of the Debt, the Work of Mourning and the New International, trans. Peggy Kamuf (1994; reprint, New York: Routledge, 2006), 74.

${ }^{17}$ Ibid., 28 (emphasis in original).

${ }^{18}$ Ibid., 33.

${ }^{19}$ Adam Thurschwell, "Specters of Nietzsche: Potential Futures for the Concept of the Political in Agamben and Derrida," Cardozo Law Review 24, no. 3 (2003): 1199.

${ }^{20}$ Derrida, Specters of Marx, 81.

${ }^{21}$ Catts and Zurr, "The Art of the Semi-Living and Partial Life," 9.
} 
Catholic archbishop who considered it blasphemous. ${ }^{22}$ TC\&A's artists speculate that these objections of blasphemy are rooted in the perception that they were "disfiguring the image of God" by manipulating the human form in Extra Ear. ${ }^{23}$ Indeed, one could not recognize the tissue-cultured ear in Extra Ear as blasphemous without first having identified its sacred or religious qualities, and hence making a moral calculation based on an other whose identity had already been determined. ${ }^{24}$

In making the claim that TC\&A's work gives rise to an ethical moment in which the other calls for and demands a response, my argument follows scholarly accounts of the animal that attempt to respect the other's alterity. ${ }^{25}$ Nicholas Ridout cautions that the ethically motivated attempt to recognize the other in the nonhuman animal in art and performance "resist[s] making anything (meaningful) of these animals and their situation." ${ }^{26}$ For Ridout, performance studies' rehearsal of the Heideggerian concern for leaving the animal "as it is" and the Lévinasian call to let the other be in its alterity can "involve a wilful suppression of affect as well as an evasion of political responsibility." 27 Derrida's messianic without messianism (as I have appropriated it here) instead offers an opportunity to acknowledge both affect and meaning-making in the spectatorial encounter with TC\&A's images. The specifically "messianic" appearance of TC\&A's Semi-Living sculptures, for example, ensures the recognition that they are placed and / or read as a sign that "makes meaning." These images, like Derrida's motif, retain the idea of messianism through their references to religious iconography, even while they refuse to offer responses in accordance with a particular religion (Christian, Judaic, Islamic, and so on). Furthermore, it is through these religious connections, coupled with the knowledge that these sculptures are potentially alive, that affect is also stirred by this evocative imagery. Ridout's concerns about an ethics of otherness are therefore addressed by the dual recognition of the play of religious iconography (as sign and affect) in TC\&A's images. Appropriating Derrida's messianic without messianism in this way addresses both the possible political and affective dynamics that are available through an ethical relation to the Semi-Living as other in TC\&A's documentation. ${ }^{28}$

Attending to documentation-artists' text and commentary, documentary photographs, artists' images, scholarly papers, and so on-is vital to a critical reflection on an ethics of reception because it is the predominant mode through which TC\&A's

\footnotetext{
${ }^{22}$ Damien Casey, "Sacrifice, Piss Christ and Liberal Excess," Law, Text, Culture 5 (2000): 20. For more on this exhibition, see Anthony Fisher and Hayden Ramsay, "The Bishop, the Artist, the Curator and the Crucifix," Quadrant 41, no. 12 (1997): 48-53, available at http://search.informit.com.au.ezproxy.library. uq.edu.au/documentSummary; dn=040833082231726;res=IELLCC (accessed 1 March 2014).

${ }^{23}$ Catts and Zurr, "The Art of the Semi-Living and Partial Life," 9.

${ }^{24}$ Although it is beyond the scope of this essay, the theoretical model applied here helps to articulate the different ethical demands of the Semi-Living other of TC\&A's artistic practice in comparison with the other in an animal rights or environmental ethics context. In these areas, the other is known and already determinable_-for example, as animal (not human) and victim (not perpetrator)—whereas the frame of reference for tissue-cultured sculptures that appear in an artistic context is not already limited by a dominant or fixed discourse.

${ }^{25}$ See, for example, Steve Baker, The Postmodern Animal (London: Reaktion Books, 2000); David Williams, "The Right Horse, the Animal Eye: Bartabas and Théâtre Zingaro," Performance Research 5, no. 2 (2000): 35-36; and Parker-Starbuck, "Becoming-Animate," 668.

${ }^{26}$ Ridout, "Animal Labour in the Theatrical Economy," 65.

${ }^{27}$ Ibid.

${ }^{28}$ For a reading of the political resonances of TC\&A's work that are available in the installation context, see Dixon, "Creating the Semi-Living," 411-25.
} 
work is often encountered. While I focus specifically on early examples of TC\&A's work between 2000 and 2003, the documentary images of Zurr and Catts's practice continue to have the capacity to affect through their online presence. Furthermore, an analysis of the ethical dimensions of these images prompts questions that are relevant to bioart practices, whose documentation continues to play a significant role in its wider reception. Critique is necessary where documentation has been evocatively appropriated within both journalistic and other academic contexts as a tool to make judgments about the "ethics" of the artists producing the work, or the potential of the work (or lack thereof) to engage the critical senses. ${ }^{29}$ Within the context of theatre and performance studies, photographs and artists' commentaries have often been relied upon as simply representative of a live, prior event, without critical reflection on the authenticity or reliability of these documents. ${ }^{30}$ My approach to TC\&A's documentary images is instead informed by Tagny Duff's invitation to consider documentation "not as representation or interpretation, but as in itself productive of liveness," or "eventfulness." ${ }^{31}$ Acknowledging the performative quality of TC\&A's images is a timely reminder of the play of both artistic intention in framing the spectator's response, and the interpretive work that the spectator's brings to reading the images. For the purpose of this analysis, therefore, I concentrate predominantly on the ethical dynamics of the spectatorial encounter with TC\&A's documentary images, which is where the messianic resonances are most strongly expressed..$^{32}$

The focus on documentation rather than live events may seem antithetical to the question with which I began concerning the ethical specificities of body to partial life transmission, or the relationship between the spectator and the Semi-Living sculptures that appear in TC\&A's work. However, it is important to recognize that documentation plays a key role in this relationship, whether one sits to look at online images or else stands in the gallery space looking at Semi-Living sculptures (and reading the accompanying artists' exhibition notes). I do not intend to conflate the different ethical experiences that are available either through the live event or by reading about/ seeing images of the work; instead, by pointing toward the affective quality of TC\&A's images, I wish to demonstrate that the spectator's bodily engagement with partial life as it appears in documentation is a key component in negotiating the ethical specificities of body to partial life engagement. The intention of this article is not to homogenize the ethics of encountering bioart, but instead, the analysis attempts to locate a theoreti-

\footnotetext{
${ }^{29}$ Gigliotti, "Leonardo's Choice," 22-34; Jeremy Rifkin, "Dazzled by Science," Guardian, 14 January 2003, 17. For more, see Mitchell, Bioart and the Vitality of Media, 73-74.

${ }^{30}$ Broadhurst, Digital Practices, 161-84; Gabriella Giannachi, Virtual Theatres: An Introduction (London: Routledge, 2004), 81-89, and The Politics of New Media Theatre: Life ® TM (Abingdon, UK: Routledge, 2007), 115-21; and Matthew Causey, "The Ethics and Anxiety of Being with Monsters and Machines."

${ }^{31}$ Tagny Duff, "Going Viral: Live Performance and Documentation in the Science Laboratory," Performance Research 14, no. 4 (2009): 38 (emphasis in original).

${ }^{32}$ Unfortunately, there is not enough space here to critique other forms of documentation in TC\&A's work. I therefore accept at face value some of the artists' writings. I mainly use statements that provide the reader with the context within which Catts and Zurr frame these works, and have verified factual evidence through ongoing correspondence with the artists. For a critical reflection on TC\&A's artists' documentary writing on the Semi-Living, see Adele Senior, "Towards a (Semi-)Discourse of the Semi-Living: The Undecidability of Life Exposed to Death," Technoetic Arts: A Journal of Speculative Research 5, no. 2 (2007): 97-112.
} 
cal framework for understanding the ethical nuances of the spectatorial experience of documentation in the work of TC\&A as a leading art collective in the area of bioart. ${ }^{33}$

This essay first examines the religious resonances in the documentary images of Pig Wings, Disembodied Cuisine, and Tissue Culture and Art(ificial) Wombs in order to draw out the ethical dimensions of encountering TC\&A's work through documentation. It then argues that TC\&A's documentary images occasion an ethical experience of responsibility to the Semi-Living as other, and suggests that by acknowledging the messianic aesthetic at work in these images, we can see how this experience of otherness can be foreclosed in the spectatorial encounter. The essay concludes by offering some considerations for navigating the ethical landscape of bioart at a time when it has become much more commonplace in the biotechnological era to grow living material outside of the body, both within and beyond an artistic context. By examining ethics in the reception of the Semi-Living, the essay invites a number of wider questions: What is our ethical and political relationship to life that exists beyond the body from which it originated? How do we conceive of our ethical obligations and position in relation to life that is not (yet) an "organism"? And what value do we attach to this life (or semi-life) through the documentary traces that dominate its reception?

\section{Giving Birth to Pig Wings}

The association made between the Extra Ear and blasphemy is prompted by the staging and framing of the installation itself, as well as the religious connotations that resonate through TC\&A's earlier practice. The Kapelica gallery in Slovenia where TC\&A premiered Extra Ear using human tissue, for example, was once a church, and the artists intentionally played with its architectural references to that history. ${ }^{34}$ The sterile hood and the necessary laboratory equipment for keeping the sculpted ear living and growing were presented on a stage where the altar once appeared. This sitespecific performance emphasized the "ritualistic aspects of the nurturing act" involved in tissue culturing, which the artists have elsewhere likened to Julian Huxley's "The Tissue Culture King," ${ }^{35}$ the story of a British scientist whose tissue-culture techniques among an African tribe led to the replacement of their worship of the tribe's king and its ancestors with the religious and ritualistic worship of living fragments. ${ }^{36}$ Reference to this narrative confirms the artists' attempts to draw parallels between a biotechnical concern with bodily fragments and a religious attendance to relics. Further confirmation of these religious overtones are offered in a paper that documents the installation, where the artists use the term relics to refer to the artificial molds of Stelarc's ear that were produced in the process of creating Extra Ear. ${ }^{37}$ Displayed in a glass case in the

\footnotetext{
${ }^{33}$ Catts and Zurr have distanced themselves from other "bioart" practices that (for them) parallel rather than critique genehype and the "hyperbolic discourses of molecular biology"; see Oron Catts and Gary Cass, "Labs Shut Open: A Biotech Hands-on Workshop for Artists," in Tactical Biopolitics: Art, Activism, and Technoscience, ed. Beatriz da Costa and Kavita Philip, 143-56 (Cambridge, MA: MIT Press, 2008), esp. 149. Nevertheless, TC\&A's practices, especially their vast and publicly available documentary materials, have been fundamental to the reception of bioart within the academy. For further evidence of TC\&A's influence on bioart as a "movement," see Rafferty, "Regeneration," 82-99.

${ }^{34}$ Catts and Zurr, "The Art of the Semi-Living and Partial Life," 9.

${ }^{35}$ Julian Huxley, "The Tissue Culture King," in Great Science Fiction by Scientists, ed. Groff Conklin, 145-70 (New York: Collier, 1962).

${ }^{36}$ Catts and Zurr, "The Art of the Semi-Living and Partial Life," 4.

${ }^{37}$ Ibid., 8.
} 
installation space, these sculptures are framed as relics (from the Latin reliquiae, meaning "remains") that cite those objects or parts of the body retained in museums and churches for their historical and religious significance.

Although the religious references are more explicit in Extra Ear, the allusion to religious iconography in TC\&A's work appears much earlier, in a project between 2000 and 2002: Pig Wings. This piece is framed by the artists in response to what they perceive to be the inflated "rhetoric of the media as well as public and private developers of bio-medical technologies." ${ }^{38}$ The artists suggest that this rhetoric has "created public anticipation for less than realistic outcomes," and they assert that a polarized discourse of biotechnology has encouraged the perception of biotechnology in either utopian or dystopian terms. ${ }^{39}$ In Biotechnology and Culture: Bodies, Anxieties, Ethics, Paul Brodwin also notes the tendency toward either a technophilic or technophobic discourse within "popular media accounts as well as scholarly analysis," serving either to celebrate or generate fear about advancements in biotechnology. ${ }^{40}$ More specifically, Pig Wings was first commissioned to respond to the supposed completion of the Human Genome Project, despite the fact that the artists choose not to use genetic technologies within their practice. ${ }^{41}$ Their artistic response to the commission was to critique the "exaggerated claims and overstatements concerning DNA and the Human Genome Project" 42 by creating wings for pigs in a deliberate and humorous play on the popular idiom "pigs might fly." Catts and Zurr grew miniature wings out of pig bone tissue and polymer scaffolds that had been shaped into the wings of a Pterosaur, a bird, and a bat, or "the three solutions for flight in vertebrates." 43 By using these wing shapes, the artists intentionally reference the winged body of culture "as either good/angelic (bird-wing) or evil/satanic (bat-wing)," along with the wings of the Pterosaur-a now extinct flying reptile of the Triassic period, which they suggest is more culturally neutral. ${ }^{44}$ The "good, the bad, and the extinct" capture, for the artists, the socio-cultural values that are attached to gene technologies, as they argue that "the interpretation of genes is not a value-free process." 45

Figure 1, which is taken from one of the Pig Wings (2002) installations, shows a custom-made laboratory on the right-hand side where the miniature Semi-Living sculptures were kept alive for the duration of the installation. To the left of the image are some enhanced photographs of the different wing versions on which the sculptures have been modeled and to which a culturally associative color has been added. This image recalls other artistic interpretations of religious scenes in which angels figure, particularly those events of the Annunciation, the Nativity, and the Resurrection.

\footnotetext{
${ }^{38}$ Oron Catts, Ionat Zurr, and Guy Ben-Ary, "Pig Wings" (2002), available at http://www.symbiotica. uwa.edu.au/activities/exhibitions/biofeel (accessed 17 September 2013).

${ }^{39}$ Ibid.

${ }^{40}$ Paul Brodwin, Biotechnology and Culture: Bodies, Anxieties, Ethics (Bloomington: Indiana University Press, 2000), 5.

${ }^{41}$ For a detailed background on the Pig Wings project, see Ionat Zurr and Oron Catts, "Big Pigs, Small Wings: On Genohype and Artistic Autonomy," Culture Machine 7 (2005), available at http://www. culturemachine.net/index.php/cm/article/viewArticle/30/37 (accessed 6 February 2014).

${ }^{42}$ Ibid.

${ }^{43}$ Ionat Zurr and Oron Catts, "The Aesthetics of Parts: Humans and Other Animals Are 'Becoming' Each Other" (2007), available at http://www.tca.uwa.edu.au/pig/parts.html (accessed 17 September 2013). ${ }^{44}$ Ibid.

${ }^{45}$ Zurr and Catts, "Big Pigs, Small Wings."
} 


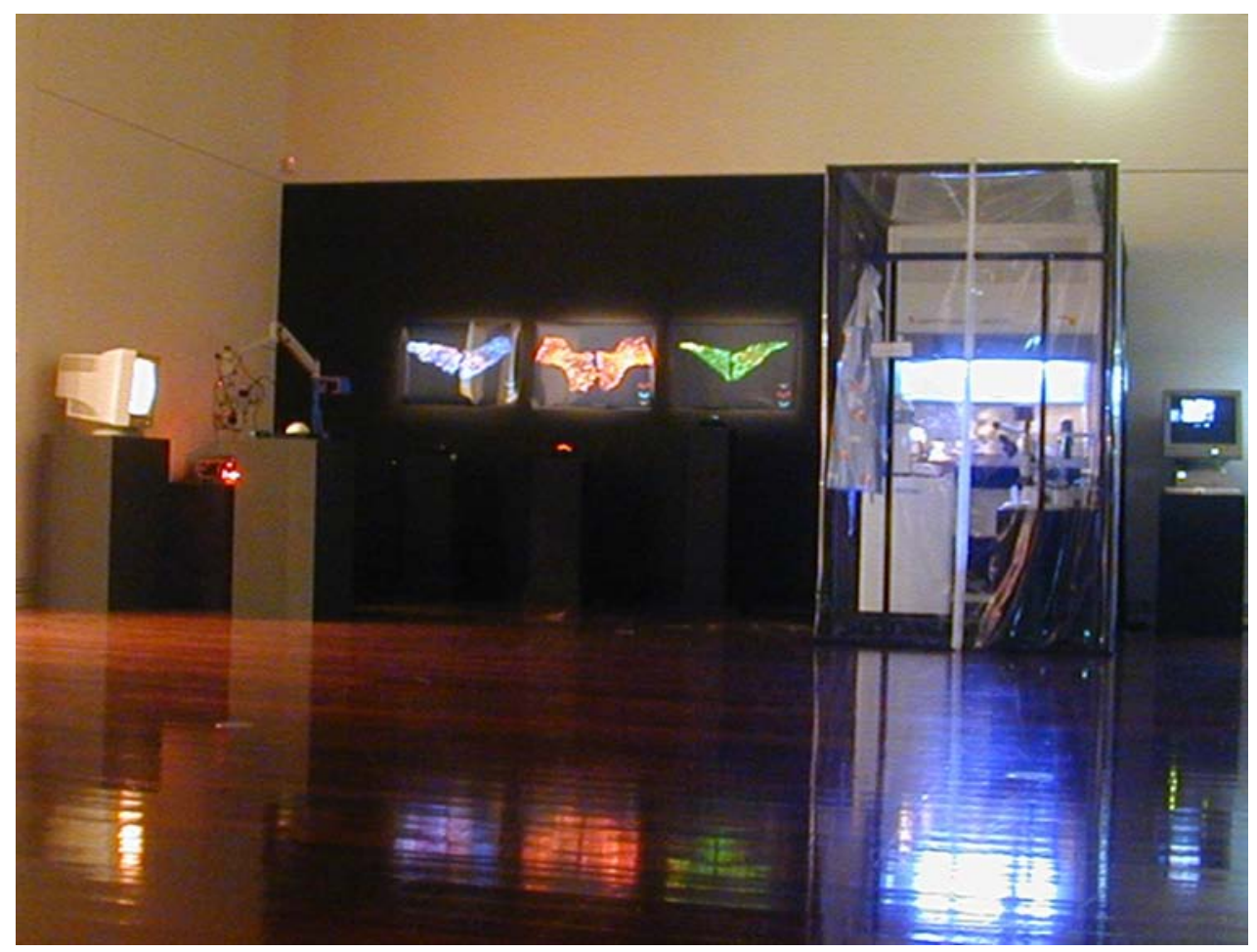

Figure 1. Pig Wings, installation, Adelaide, Australia (2002). (Photo: TC\&A.)

TC\&A's photo, in particular, bears a striking resemblance to an early-fifteenth-century painting of The Nativity (ca.1420) by the Master of Flémalle, ${ }^{46}$ which echoes the motif of a trinity of winged beings. Above the stable, overlooking the Nativity scene, the angels in Flémalle's painting don clothing that is marked with the same colors as the wings in the installation photo: blue, red, and green. In religious artistic representation of angels, the color of the clothing and the wings, as well as the wing detail, is often used as a signifier for indicating the identity or type of angel pictured ${ }^{47}$ Similarly, the colors used by Catts and Zurr are incorporated to represent the different wing versions that the Semi-Living sculptures have been modeled on: aves (bird), chiropteran (bat), and Pterosaur ("winged lizard"), or "blue for angelic, red for evil and green for the dinosaurs." ${ }^{48}$

In Flémalle's Nativity scene, the angels witness the coming of the Messiah. Holding a banner with an inscription on it, they fulfill their role as messengers of God, as intermediaries between heaven and earth. Angel, after all, derives from the Greek ángelos, meaning "messenger." Similarly, TC\&A's installation image shows these three vibrant wings overlooking the Semi-Living sculptures that sit in a bioreactor in the

\footnotetext{
${ }^{46}$ The Master of Flémalle's The Nativity can be viewed online at http://mba.dijon.fr/sites/default/files/ public/scolaire/pdf/fiche_flemalle_2edegre.pdf (accessed 4 March 2014). Flémalle is understood to be the painter Robert Campin. For more on this painting and its iconography, see Georges H. de Loo, "An Authentic Work by Jacques Daret, Painted in 1434," Burlington Magazine 15 (1909): 202-8.

${ }^{47}$ Nancy Grubb, Angels in Art (New York: Artabras, 1995), 13.

${ }^{48}$ Oron Catts, “Art, But Not as We Know It,” New Scientist 181, no. 2346 (2004): 44-46.
} 
installation. Echoing the elevated position and order of Flémalle's angels, the wings on the right and left are staged to deliver the messages of creationism (blue for the divine) and evolutionism (green for earth/Triassic period) through their signifying colors and figuration. These two wing images dramatize the tension between, on the one hand, Christian doctrine that asserts the role of divine intervention and argues that humankind descended from Adam and Eve, and on the other the evolutionary belief in a history that predates humankind. While the photo echoes the messianic quality of Flémalle's painting, neither God nor evolution has created the Semi-Living sculptures that are the subject of this image.

This is where the centrally placed red pair of wings signifies much more than the "evil" attributed to them by the artists. In particular, they capture what is deferred and unknowable when, as spectators, we occupy these positions of evolutionism and creationism as belief systems. The red wings do not represent a faith in the same way that the blue and green wings do, so they are a reminder that we cannot have faith without the possibility and deferral of doubt, which in broad terms is the rejection of evolutionist claims by creationists (and vice versa). The red coloring of the central wings brings with it a demonic quality that disrupts and disturbs the ability of creationism and evolutionism (as messianisms) to account for the Semi-Living other that remains unseen in the photo. Demons, for some denominations of Christianity, are the "sons of God" described in Genesis (6:4) as mating with the "daughters of men" to create Nephilims (also translated as "giants")—an angel/ human hybrid..$^{49}$ The demonic, in this respect, has an already-established relationship to the "rebellious" act of crossbreeding that is performed by these "fallen angels" against the will of God. Conversely, for the evolutionary perspective (green), the possibility of the demonic is that which lies outside of scientific understanding, such as the "supernatural" phenomena of heaven and the divine (blue). As such, the red wings juxtaposed with the blue and green wings enact the same challenge to these belief systems that is also made by the Semi-Living sculptures as creations of tissue engineering (fig. 2).

Neither a product of evolution nor a descendent of Adam and Eve, there is an other in TC\&A's installation image (see fig. 1) who/that still demands a faithful response. Derrida argues that "[y]ou cannot address the other, speak to the other, without an act of faith"; ; faith, in Derridean terms, is open to the coming of something undeconstructible, something unanticipated, because religion can be deconstructed, whereas faith cannot. The faith that the wings in TC\&A's image seem to herald is an ethical response that "cannot be determined by a given religion," 51 but that, at the same time, this response still depends on a reference to religion for its meaning. Figure 1 occasions a relation of faith precisely by referencing and undermining the stability that a faith in these religious and evolutionary origins appears to promise. The wing images in particular reinforce this invitation of faith by echoing a different kind of in vitro (meaning "on glass") representation: the stained-glass window. The semi-aliveness of stained glass in its ability to engage the imagination in playing out its narrative can be felt in Catts

\footnotetext{
${ }^{49}$ The Holy Bible, English Standard Version, Crossway Bibles, available at http://www.gnpcb.org/esv/ (accessed 6 January 2012).

${ }^{50}$ Jacques Derrida, “The Villanova Roundtable: A Conversation with Jacques Derrida," in Deconstruction in a Nutshell: A Conversation with Jacques Derrida, ed. John D. Caputo, 1-28 (Bronx, NY: Fordham University Press, 1997), quote on 22.

${ }^{51}$ Ibid.
} 

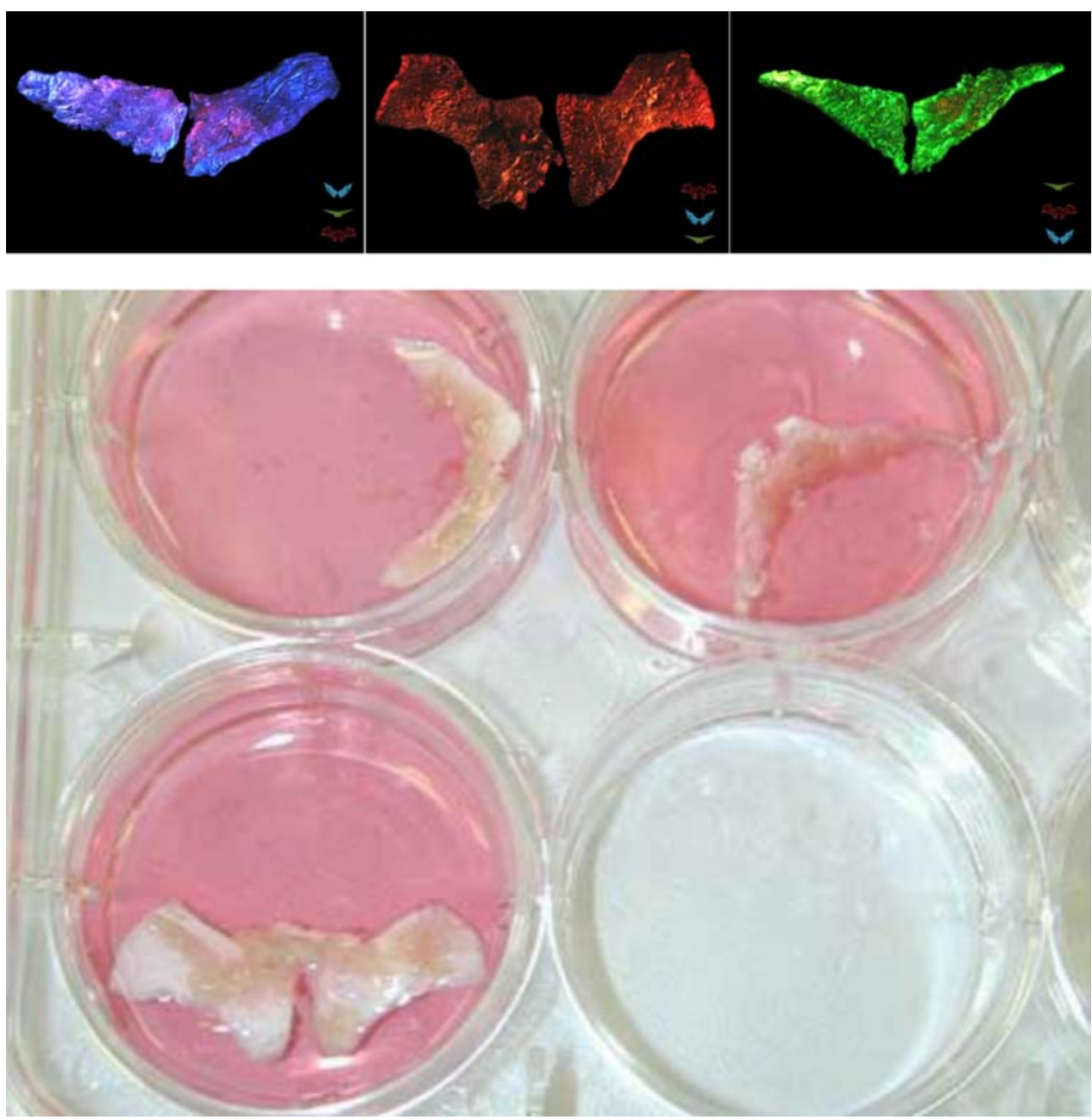

Figure 2. Top: Enhanced images of TC\&A's Pig Wings sculptures. (Photo: TC\&A.) Bottom: Pig bonemarrow stem cells, differentiated into bone tissue (approx. 40 × $10 \times 4 \mathrm{~mm}$ each set). Cultured and grown for nine months in shapes of wings. (Photo: Oron Catts, Ionat Zurr, and Guy Ben-Ary.)

and Zurr's set of three brightly colored wings. Haunted by the stained-glass window of the pre-Reformation Christian iconographic tradition, the wing images are selfreferential in their invitation to the spectator to engage in an idolatrous relationship. TC\&A's wings are, therefore, simultaneously sacred and sacrilegious: idolatrous in their reference to sacred imagery, and iconoclastic in their perceived tampering with it. On the one hand, the wings are haunted by the history of religious iconography, and on the other by the undeterminable future of a Semi-Living "object/being" that is partly grown and partly constructed by means of human intervention.

The evocative religious and messianic resonances in these images of Pig Wings have the potential to generate affect, either as a feeling and/or as occasioning an ethical encounter with the other. By this, I mean that the documentary spectator, like the gal- 
lery spectator for Mitchell, has the "capacity-for-being-affected." $52 \mathrm{He}$ observes that the feelings of being disturbed, fascinated, or dazzled by bioart have previously been explained (away) in either naturalist or psychological terms..$^{53}$ Journalistic commentaries have treated feelings of disgust and repugnance as a completely "natural" reaction to bioart, while some academic critics have interpreted bioart's ability to dazzle "through a narrowly psychological lens, suggesting that insofar as vitalist bioart dazzles and fascinates, it renders spectators and bioartists passive, disabling their capacities for critical reflection." ${ }^{54}$ While Mitchell suggests that these claims are reductive and fail to account for the complex experience of being in the gallery, this critique can also be extended to the very documentary experiences on which these claims are often founded. The spectator who wishes to avoid the undecidability that is felt both through the invitation to make meaning and through the affective quality of the image reduces and fixes meaning from a stable position either through moral, psychological, or other messianisms; while, on the other hand, the spectator of these images who attempts to remain open to the unseen other in all its alterity has the capacity for being affected by "becom[ing] linked in new ways to his or her surroundings." ${ }^{55}$ In particular, where these "surroundings" are documentary, the invitation of openness results in "an active transformation of a state of affairs," rather than "a reaction to a state of affairs." ${ }^{56}$ In my analysis, this active transformation thus takes the form of seeing documentation not (only) as an index of a live event, but as encouraging an ethical response in and of itself.

The idea that being open to the other leads to active transformation provocatively suggests that the spectator of documentation might also possess what Mitchell calls the gallery spectator's "capacity-for-affecting," 57 in addition to her capacity for being affected. The gallery spectator who participates in TC\&A's signature "killing ritual" in which she is invited to choose whether or not to accelerate the "death" of the sculptures by touching them undoubtedly demonstrates a capacity for affecting. Indeed, the action of touching leads to the eventual death of the living tissue because the fungi and bacteria that live on human hands contaminate the sculptures. However, the documentation spectator's capacity for affecting has perhaps been overlooked. I suggest that by allowing herself to be affected by TC\&A's images of Pig Wings, the spectator might affect a change in the discourses of the academy and journalism that simply react rather than respond to such images. It is through an ethical openness to the other that the messianisms, which enable these reactions to arrive at their fixed meaning, are revealed.

\section{Feasting on Frog Steaks}

Disembodied Cuisine (2003) further explores this capacity for affecting in the gallery by staging the ethically problematic relations of consumption and exploitation with the Semi-Living sculptures. As part of the exhibition, L'Art Biotech in Nantes, France, TC\&A cultured in vitro what they refer to as a "Semi-Living steaks" by growing (in the gallery) frog-derived cells over steak-shaped biopolymer scaffolds alongside living

\footnotetext{
${ }^{52}$ Mitchell, Bioart and the Vitality of Media, 76.

${ }^{53}$ Ibid., $73-75$.

${ }^{54}$ Ibid., 73.

${ }^{55}$ Ibid., 75 .

${ }^{56}$ Ibid. (emphasis in original).

${ }^{57}$ Ibid., $75-76$.
} 


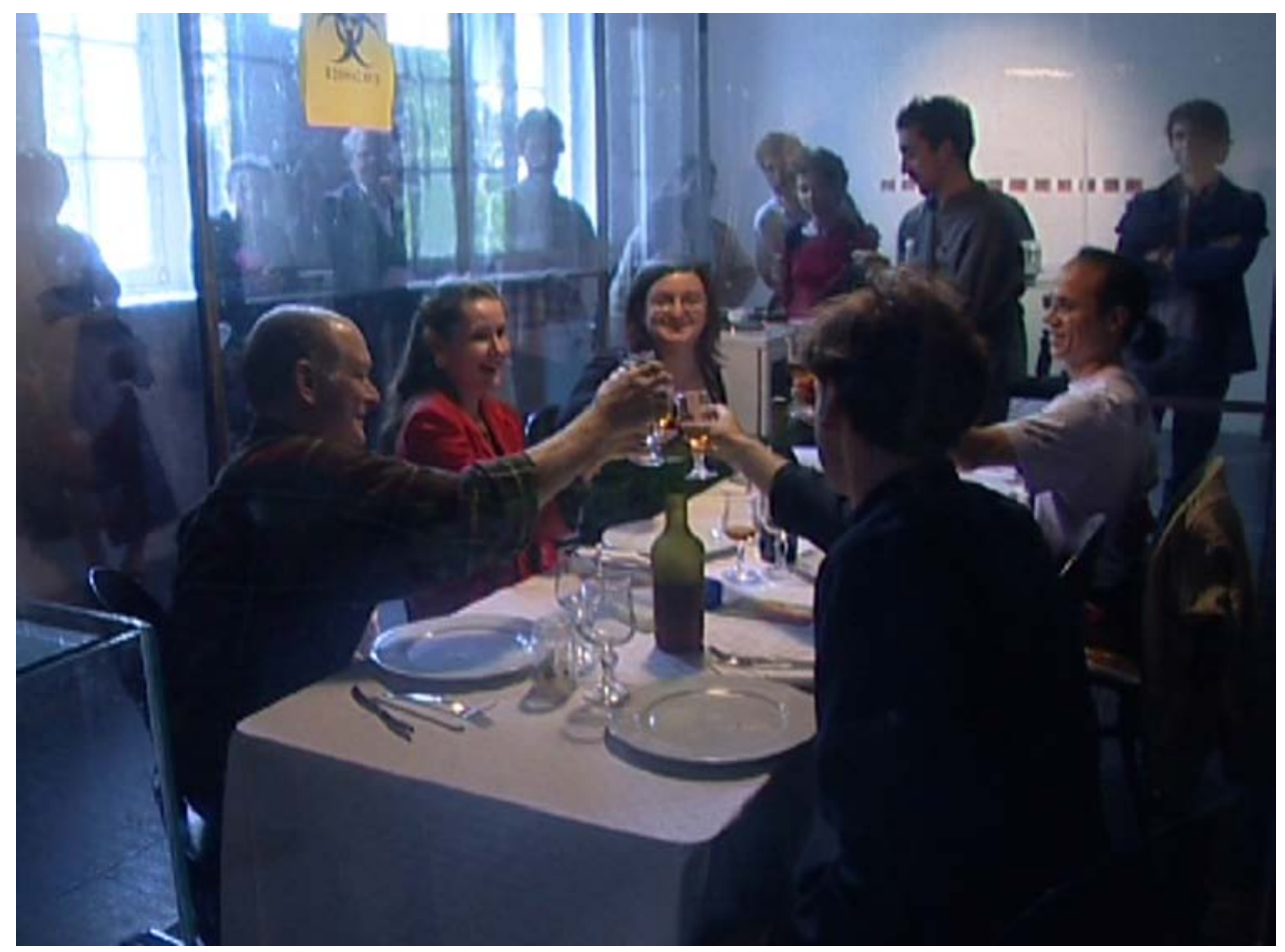

Figure 3. Disembodied Cuisine, exhibition view from L'Art Biotech, Le Lieu Unique, National Arts and Culture Center, Nantes, France (2003). (Video still: Jens Hauser and Gérard Sergent.)

frogs. The installation concluded with a "feast" in which the steaks were cooked by a French chef and served to volunteers from the audience as a "nouvelle cuisine-style dinner." ${ }^{58}$ By engaging the installation spectator in a relationship of consumption with the Semi-Living sculpture, the project "deals with one of the most common zones of interaction between humans and other living systems and will probe the apparent uneasiness people feel when someone 'messes' with their food while also exposing the inconsistency of the ethical framework our society sets up for dealing with nonhuman living systems." ${ }^{59}$

The cells that were used in the creation of the steaks were taken from an existing cell line developed in the late 1980s from the skeletal muscle cells of a tadpole of an aquatic toad (Xenopus laevis). ${ }^{60}$ The steaks were originally intended to be grown from a biopsy taken from the frogs that featured in the installation, but for practical reasons this was not possible. Nevertheless, the frogs in the installation still retained their symbolic significance as the biopsied "healing" donors for the Semi-Living steaks, and were released into a botanical garden at the end of the exhibition. ${ }^{61}$ Disembodied

${ }^{58}$ Oron Catts, "The Art of the Semi-Living," in Live: Art and Performance, ed. Adrian Heathfield, 152-59 (New York: Routledge, 2004), esp. 159.

${ }^{59}$ Zurr and Catts, "Are the Semi-Living Semi-Good or Semi-Evil?" Technoetic Arts: A Journal of Speculative Research 1, no. 1 (2003): 58.

${ }^{60}$ Ionat Zurr and Oron Catts, "Victimless Utopia or Victimless Hypocrisy?" (2007), unpublished paper, available at $h$ ttp://boo.mi2.hr/ tom/katalog_teorija/tca\% 20text\% 20for\% 20zagreb.doc (accessed 9 January 2014).

${ }^{61}$ Zurr and Catts, "The Ethical Claims of Bioart," 13. 
Cuisine, therefore, "ironically offered the possibility of eating meat without killing animals" by creating victimless steaks from an existing immortalized cell line. ${ }^{62}$ The irony of the project is to be found in the fact that the steak is not victimless because the nutrients, hormones, and growth factors used to keep tissue-cultured steaks alive is animal-derived. Fetal calf serum is one such product, which is often used as a nutrient solution to keep cells/tissues alive in vitro and is created through a method of collection that involves killing a calf older than three months. ${ }^{63}$ Despite there still being a victim in TC\&A's "victimless" steak and the artists' drawing attention to the irony in Disembodied Cuisine, PETA (People for the Ethical Treatment of Animals) contacted them to collaborate on the next phase of the project. Allison Carruth also notes that "they are cited in the scientific literature on in vitro meat as one of the leading research teams working on the problem of how to culture in vitro meat." ${ }^{64}$ While this acknowledges the artists' close involvement in the life sciences, both examples attest to the way in which TC\&A's documentation on its projects have taken on a life of its own and the intended "irony" has been lost in some contexts. ${ }^{65}$

Figure 3 shows participants sitting around a dinner table and raising their glasses in a toast, echoing artistic representations of the messianic event of the Last Supper. "This is my body, broken for you" resonates for the spectator who reads the artists' accompanying text, which notes that the participants sit adjacent to a tank of the living, "healing" frogs. ${ }^{66}$ Like the Messiah, who offers up the bread as his body, the living frog looks on, physically present at the feast in which resurrected fragments of its body are offered up for consumption. The circular steaks even resemble the sacramental bread often referred to as the host-from the Latin hostia, meaning "victim" or "sacrificial animal" - in the Christian ritual of the Eucharist. TC\&A's feast, as it is given to appear in this image, nods to this religious context in which the host is consumed in remembrance of the Last Supper and the self-sacrifice and/or filial sacrifice the event ordinarily signifies.

By placing emphasis on an engagement with corporeality in Disembodied Cuisine, TC\&A's feast parallels the sacred transformation of transubstantiation-the belief that the substance of the bread and wine transforms into the substance of the body and blood of Christ. This is not to deny that the "steak" brings its own symbolic significance, as its very name connotes animal(s) that are killed and eaten as food; instead, this concern with the "matter" of the Semi-Living — that is, its material and fleshy existence-is given to appear in these complementary images (figs. 4-5). Here, the Semi-Living is like the bread and wine in the Catholic Mass, which is not simply a symbol, but is the body and blood of Christ for the congregation. The focus on the materiality of the sculptures by cooking, eating, and relating them to the body of the frogs also present

\footnotetext{
${ }^{62}$ Oron Catts and Ionat Zurr, "The Ethics of Experiential Engagement with the Manipulation of Life," in Tactical Biopolitics: Art, Activism, and Technoscience, ed. Beatriz da Costa and Kavita Philip, 125-42 (Cambridge, MA: MIT Press, 2008), esp. 132.

${ }^{63}$ Ibid., 132-33.

${ }^{64}$ Allison Carruth, "Culturing Food: Bioart and In Vitro Meat," Parallax 19, no. 1 (2013): 88-100, quote on 93.

${ }^{65}$ For more on animal-welfare organizations' and for-profit companies' continued interest in the use of tissue culture to provide an alternative for animal-derived meat products, see Susan McHugh, "Real Artificial: Tissue-cultured Meat, Genetically Modified Farm Animals, and Fictions," Configurations 18, nos. 1-2 (2010): 181-97.

${ }^{66}$ Zurr and Catts, "The Ethical Claims of Bioart," 13.
} 


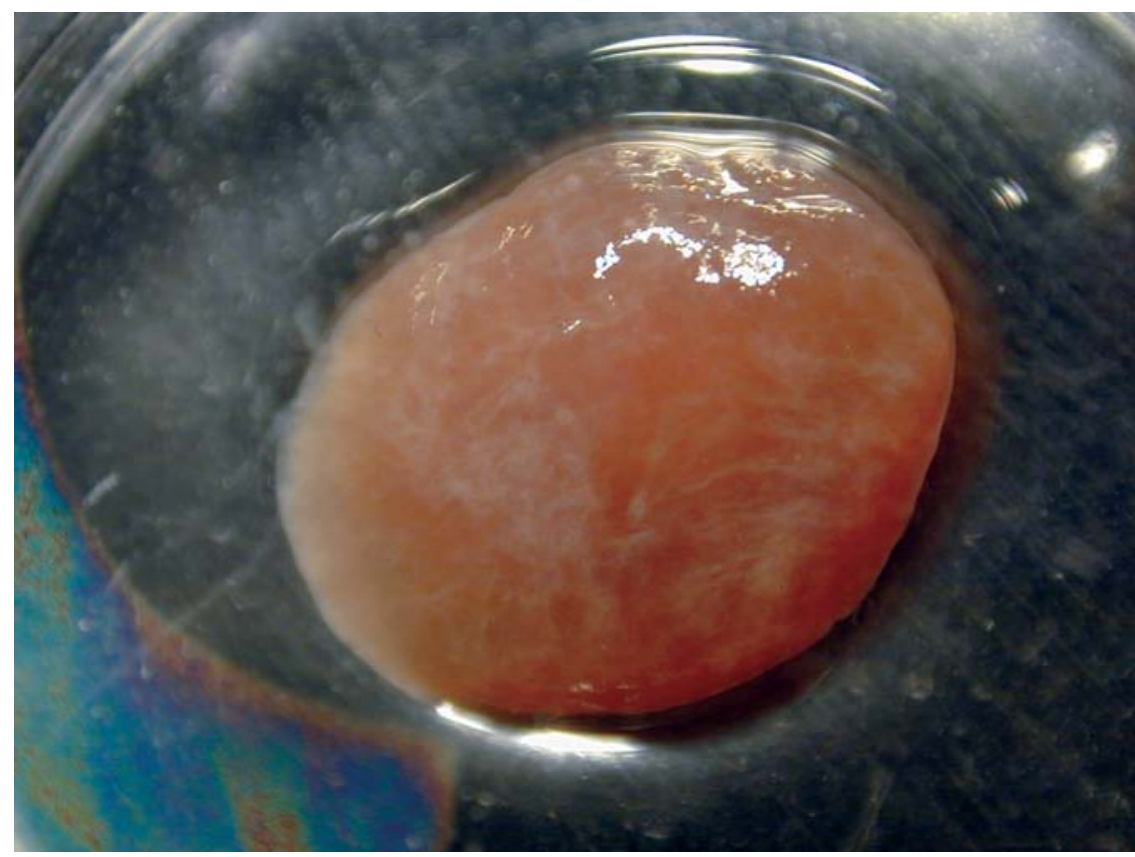

Figure 4. "Semi-Living steak," Tissue Engineering and Organ Fabrication Laboratory, Harvard Medical School, Boston (2000). Precursor to Disembodied Cuisine. Prenatal sheep skeletal-muscle cells cultured onto/into a degradable polymer (PGA) scaffold. (Photo: TC\&A.)

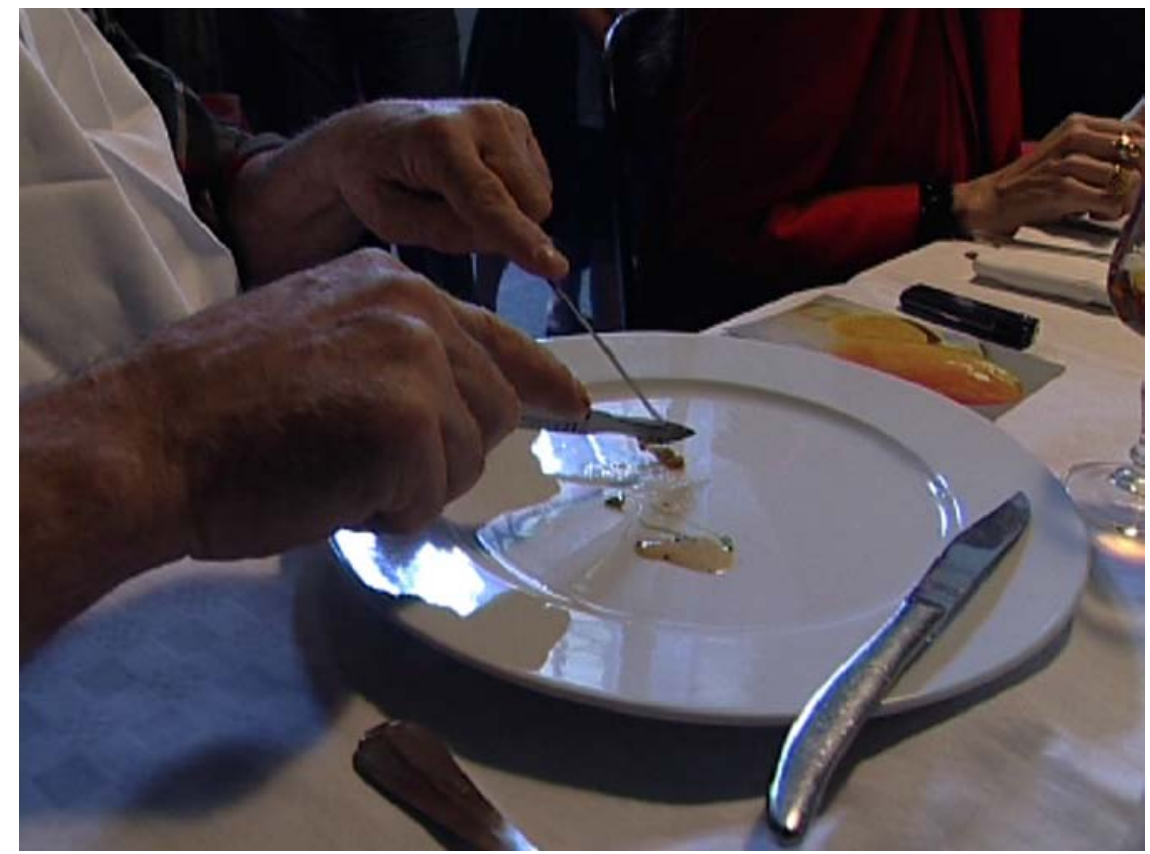

Figure 5. Disembodied Cuisine, exhibition view from L'Art Biotech, Le Lieu Unique, National Arts and Culture Center, Nantes, France (2003). (Video still: Jens Hauser and Gérard Sergent.) 
in the performance space signifies an important shift both aesthetically and ethically in TC\&A's work: from symbolic representation (Tissue Culture and Art[ificial] Wombs [2000]; Pig Wings [2002]) to bodily matter (Disembodied Cuisine [2003]; Extra Ear 1/4 Scale [2003]; Victimless Leather [2004, 2008]). ${ }^{67}$ Although the artists have not directly acknowledged this shift in their own writing, it further accounts for the association made by the NGV between Extra Ear and Serrano's Piss Christ.

The relation of the image to the messianic event of the Last Supper reinforces a reading of Disembodied Cuisine as the return of the Semi-Living (sculpture) to its "bodily processes of becoming." ${ }^{68}$ I borrow this phrase from Damien Casey, who employs it to argue that Piss Christ is "profoundly religious" in its attempt to remember the bodily processes of becoming in the Crucifixion, as opposed to being blasphemous. He suggests that the Christian Messiah's humanity, and therefore his death, is acknowledged in Serrano's artistic attempt to return the Crucifixion back to its abject qualities. Casey proposes that Serrano's photograph thus "retrieves the meaning of the incarnation." 69 These religious resonances in TC\&A's images, coupled with the images of the living frogs (fig. 6) and the fleshy steaks (see fig. 4), bring to the fore the Semi-Living as material rather than symbolic sculpture. The images' emphasis on the materiality of the Semi-Living sculptures and the knowledge that this "disembodied" steak is cooked and eaten by volunteers reinforce the abject qualities of the Semi-Living. These abject qualities have the ability to generate affect because they confront the spectator with the repressed element of animal sacrifice for human consumption.

Images of the Semi-Living steak and the breathing and living frogs (see figs. 4 and 6), from which it is said to originate, problematize any attempt to finally identify this Semi-Living other. The feast contrasts with the usual human consumption of nonhuman animals, where the other is determinable (beef or pork) and therefore the "victim" is identifiable (cow or pig). This problem of not being able to identify the other is played out in these images. We are prompted, therefore, to ask: Who or what is being remembered in this act of eating the steak? It is not the frogs who sacrificed their lives for these steaks, because they are still very much alive. The images suggest that this ambiguity as to whom the spectator of the document is expected to respond is also available to the spectator within the installation because the feast component of Disembodied Cuisine allowed an "other" to be observed (but not identified) - namely, through reference to the act of eating in the Last Supper. The feast thus staged the impossibility of not "eating" the other, since the other is always presupposed by the act of eating. ${ }^{70}$

\section{Resurrecting the Worry Dolls}

TC\&A's earlier project Tissue Culture and Art(ificial) Wombs (2000) further clarifies the status of the messianic aesthetic that I am arguing for in its work. Unlike the other

\footnotetext{
${ }^{67}$ The materiality of the sculptures is also foregrounded in a follow-up piece titled The Remains of Disembodied Cuisine (2004), where remnants of steak that was spat out by participants during the feast, because it did not taste appealing, were exhibited again in a further acknowledgment of their quasi-relic status.

${ }^{68}$ Casey, "Sacrifice, Piss Christ and Liberal Excess," 30-31.

${ }^{69}$ Ibid., 31.

${ }^{70}$ See Jacques Derrida, "'Eating Well,' or the Calculation of the Subject," in Points . . Interviews, 1974-1994, trans. Peggy Kamuf et al., ed. Elisabeth Weber, 255-87 (Palo Alto, CA: Stanford University Press, 1995), esp. 282.
} 


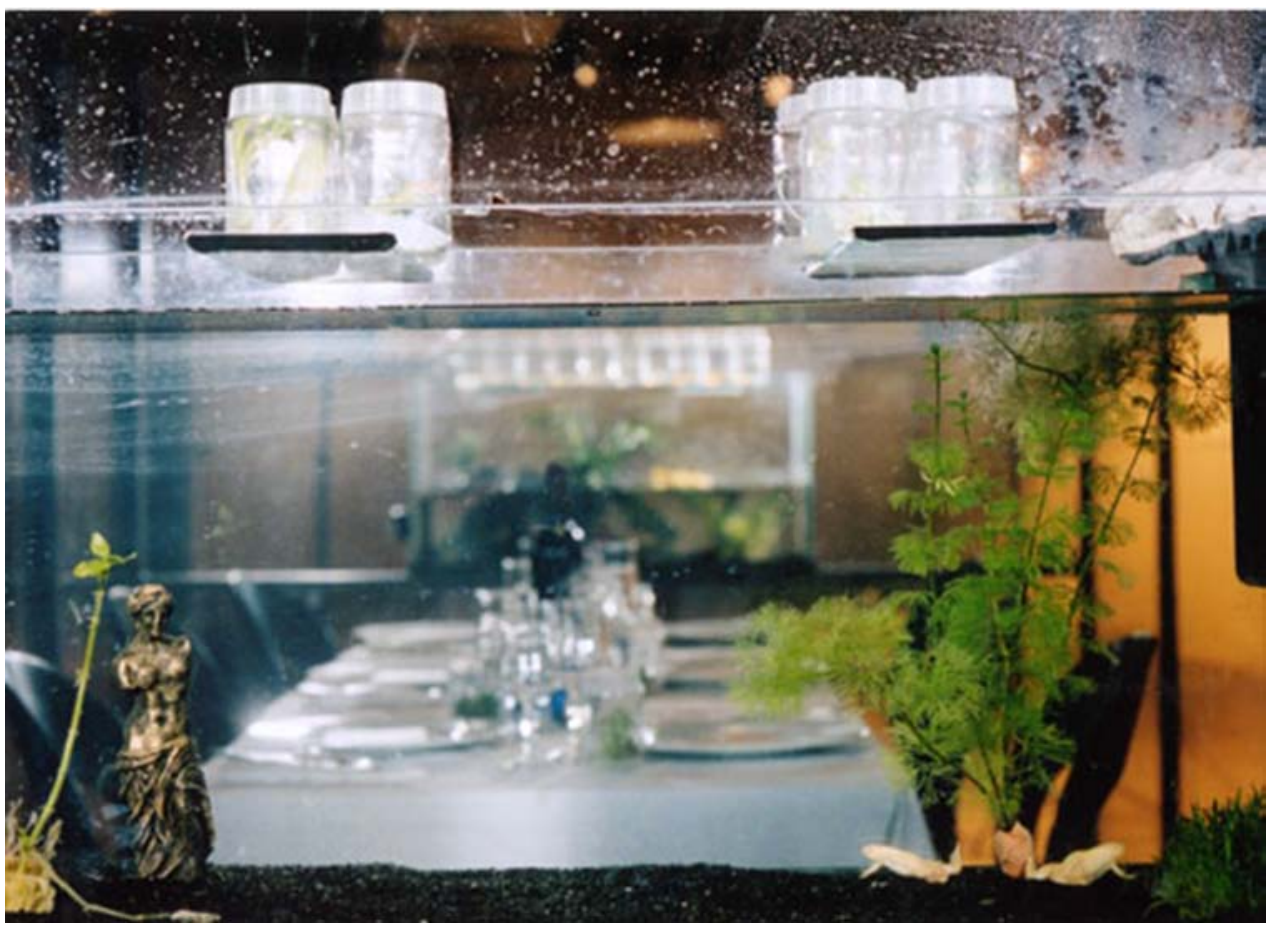

Figure 6. Disembodied Cuisine, exhibition view from L'Art Biotech, Le Lieu Unique, National Arts and Culture Center, Nantes, France (2003). (Video still: Jens Hauser and Gérard Sergent.)

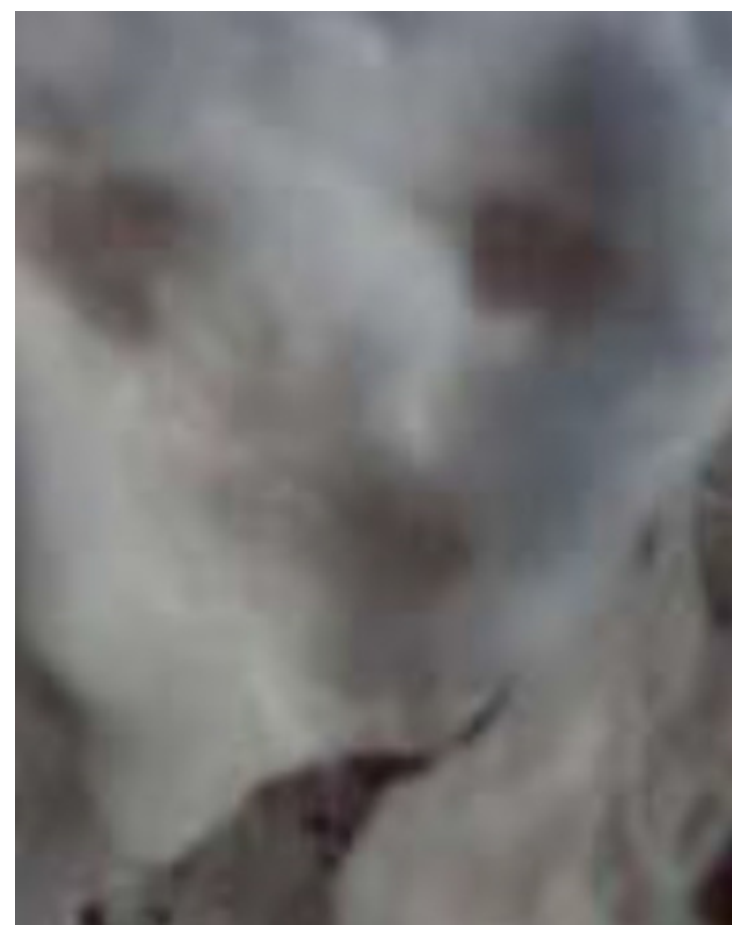

Figure 7. Biodegradable, bio-friendly polymer doll (2000). (Photo: TC\&A.) 
images, however, figure 7 is taken from the process leading up to the installation, and it is the only image among the artists' publicly available documentation on this project, which bears some resemblance to an identifiably Christian messianic event-that of the resurrection of Jesus. Its affinity to the relic of the Shroud of Turin, in particular Secondo Pia's well-known negative image, echoes the ghostly quality of this controversial relic, with its much-debated reference to the face of Jesus. The relic itself consists of the cloth that covered his body in the tomb and is thought to be marked prior to or during the Resurrection. The relation between the shroud's image and TC\&A's photograph can, however, only be read in the context of the other images I have considered thus far and in relation to the narrative of tissue culture that promises immortality. ${ }^{71}$

Pia's image, like established cell lines that are rendered "immortal" in their ability to divide infinitely, makes three promises: life after death, the resurrection or rebirth of the dead, and eternal life. However, the relation of TC\&A's photograph to the image of Jesus in the Christian iconographic tradition is debatable outside of the context of the previous images. Instead, it is the possibility of a messianic aesthetic rather than its guaranteed presence in TC\&A's documentation that gives rise to the ethical moment in which the other calls for and demands a response. Before exploring this ethical relationship further, I address the way in which Tissue Culture and Art(ificial) Wombs invites a particular kind of relation to the Semi-Living - a relation that sheds some light on the ethical response being demanded of the spectator of TC\&A's documentary traces of the project.

For Tissue Culture and Art(ificial) Wombs, TC\&A's artists grew Semi-Living sculptures based on the worry dolls of a Guatemalan tradition in which children tell their troubles to miniature cloth dolls and then place them under their pillow at bedtime with the belief that the dolls will take their troubles away. For TC\&A, the dolls "represent the current stage of cultural limbo, characterized by childlike innocence and a mixture of wonder and fear of technology" (fig. 8). ${ }^{72}$ TC\&A's version, "the Semi-Living worry doll," is, in the words of the artists, hand-crafted by using surgical sutures and biodegradable polymers that are then "seeded" with endothelial (skin), muscle, and osteoblast (bone) cells. ${ }^{73}$ These cells derive from the McCoy cell line, which originates from the synovial fluid in the knee joint of a patient with arthritis, but that has since been contaminated with mice cells and is now classified as laboratory mouse endothelial cells. ${ }^{74}$ During the installation, participants are invited to whisper their worries to the dolls or to write them down via a computer, or "worry machine."

The ghostly image of worry doll five (see fig. 7), coupled with TC\&A's reference to worry dolls that are sold predominantly as cultural artifacts and marketed as possessing divine, spiritual, magical, or therapeutic properties that enable them to eliminate worries, intensifies a reading of the Semi-Living doll as endowed with spiritual or divine significance. Online spectators of these documentary images are encouraged to tell the dolls their worries. This ritual of sharing worries with the Semi-Living again

\footnotetext{
${ }^{71}$ Adele Senior, "Haunted by Henrietta: The Archive, Immortality, and the Biological Arts," Contemporary Theatre Review 21, no. 4 (2011): 511-29.

${ }^{72}$ Oron Catts and Ionat Zurr, "Growing Semi-Living Sculptures: The Tissue Culture \& Art Project," Leonardo 35, no. 4 (2002): 365-70, quote on 368.

${ }^{73}$ Oron Catts, Ionat Zurr, and Guy Ben-Ary, "Tissue Culture and Art(ificial) Wombs" (2002), available at http://www.symbiotica.uwa.edu.au/activities/exhibitions/biofeel (accessed 17 September 2013).

${ }^{74}$ Catts and Zurr, "Growing Semi-Living Sculptures," 368.
} 


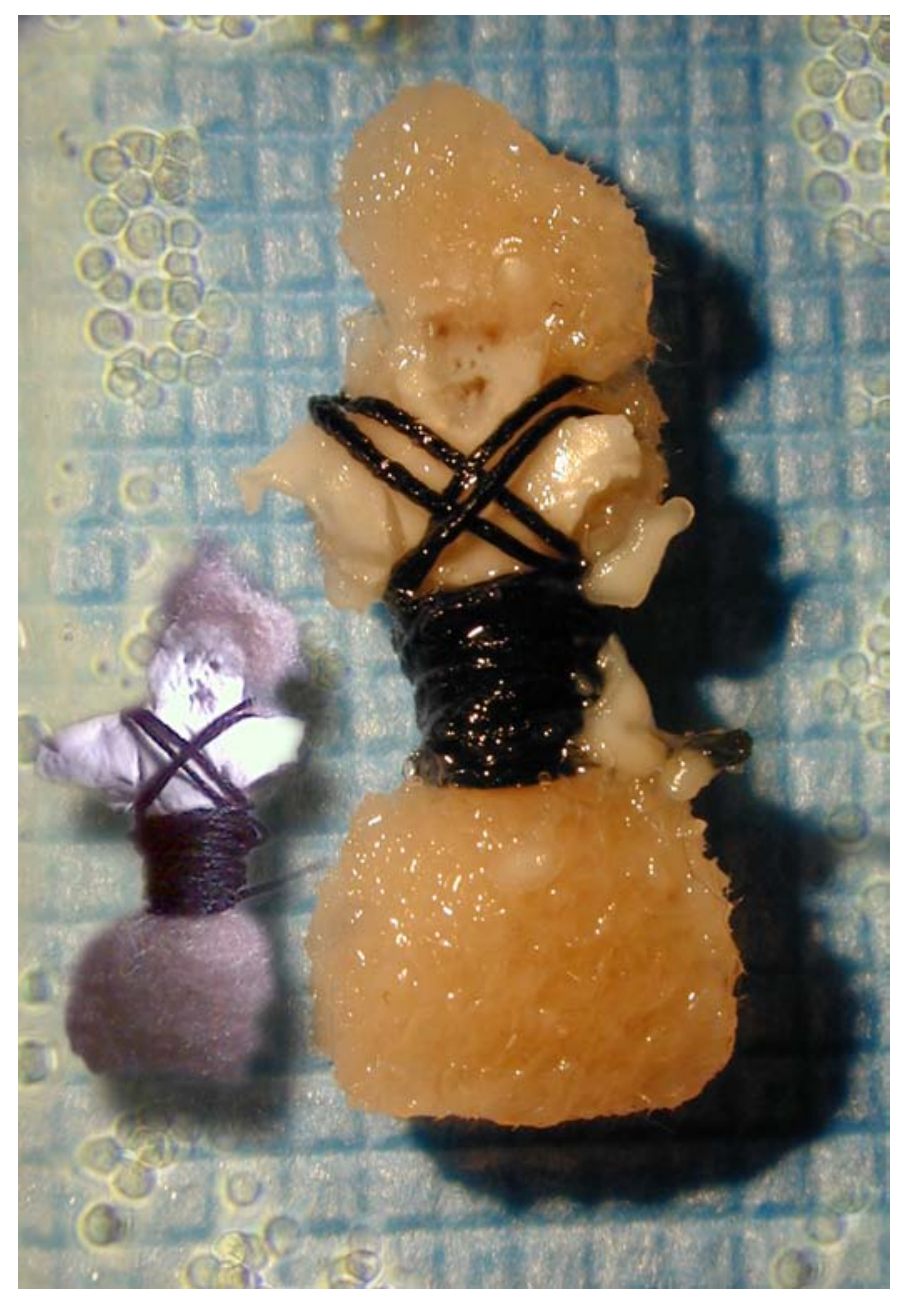

Figure 8. Semi-Living worry doll (2000). Biodegradable/bio-absorbable polymers, surgical sutures, and McCoy cell line (15 x 10 × $5 \mathrm{~mm})$.

(Photo: Ionat Zurr.)

emphasizes the Semi-Living as a relic-like, devoted "object/being," and it is often taken seriously as such. An online worrier, for example, writes what reads as a genuine request: "I want to be a doctor. Help me find direction and the strength to be one."75 By encouraging the spectator to tell her/his worries to the dolls, TC\&A's sculptures are characterized as listening to the participants, and, by listening, calling for a response from anyone who engages with them. The images of TC\&A's dolls echo this request to engage in a dialogue in a way that is not dependent on its connection to the Shroud of Turin. The dolls' conceptual history in a Guatemalan, and specifically Mayan, tradition competes with the association with the shroud in this respect: one's own interpretive work in determining the content of the images as specifically referencing Christian

\footnotetext{
${ }^{75}$ For more online posts to the worry dolls, please see "Other People's Worries," available at $h t t p: / /$ www.tca.uwa.edu.au/guestbook/guest.asp (accessed 6 January 2012).
} 
iconography is put into question. Unlike the previous images, TC\&A's images of the Semi-Living dolls require a leap of faith, so to speak, to establish this connection with the Christian iconographic tradition.

Whether or not readers agree that TC\&A's images draw on Christian iconography, they are nevertheless messianic in the respect of inviting the spectator to remain open to an unknowable, undeterminable other. In its potential relationship to the Christian Messiah, TC\&A's aesthetic encourages a faith without determined faith that is required in the ethical moment "beyond both debt and duty . . . beyond human responsibility." ${ }^{76}$ It is not difficult to see, therefore, how the duty of "human responsibility" toward one's visitors or indebtedness to one's funders/sponsors may lead a gallery, for example, to make a political decision that forecloses an ethical experience of absolute otherness. What is at stake in foreclosing this ethical experience of the other, which Derrida inherited from Emmanuel Lévinas? ${ }^{77}$ By naming and categorizing the other, we disregard its alterity; in Derridean terms, this is unethical because it gives rise to a predetermined ethical response that is founded on a calculation-for example, the human other takes priority over the animal other-which simply applies an existing set of rules or ethical frameworks in accordance with a particular messianism. A simple application of rules for how to be ethical does not constitute an ethical response to the forms of life in art and science that have yet to be anticipated. The Semi-Living is one such example that disturbs attempts to reduce it to the same. By endeavoring to respect the Semi-Living's alterity and consider the specific ethical encounters that are made available through sign and affect in TC\&A's images, I offer some considerations below that intend to navigate (rather than anticipate) some of the ethical dimensions of encountering bioart in the future.

\section{Toward an Ethics of the Semi-Living}

An ethics of the Semi-Living should not only be concerned with the material sculptures of TC\&A's practice, but also the conceptual, discursive, and textual conditions of possibility that constitute the Semi-Living as such and enable it to escape definitive signification. The Semi-Living, in this respect, is that which includes, but is not reducible to a term, a sculpture, a product of discourse, a concept, or a material thing. ${ }^{78} \mathrm{My}$ use of the term acknowledges its dependence for meaning on other forms, discourses, messianisms, or expressions of life through which it appears. These expressions might include biological life, politically qualified life, bare life, or meat/material to be visually or physically consumed. This is where an ethics of the Semi-Living can help to identify the ethical specificities of body to partial life transmission in bioart more generally and draw attention to the nuances of negotiating bioart through documentation. For example, while the spectator of TC\&A's documentary images is not placed in the singular position of responsibility for the life or death of the sculpture, she or he is faced with the ethical dilemma of all the "other others" to which the Semi-Living points: the cells that are discarded in the process of creating a Semi-Living sculpture; the absent sculptures that do not make it to the gallery; and the calves that are routinely killed to supply nutrients to keep in vitro cells.

\footnotetext{
${ }^{76}$ Jacques Derrida, The Gift of Death, trans. David Wills (Chicago: University of Chicago Press, 1995), 63.

${ }^{77}$ Emmanuel Lévinas, Totality and Infinity: An Essay on Exteriority, trans. Alfonso Lingis (Pittsburgh: Duquesne University Press, 1969).

${ }^{78}$ For more on this topic, see Senior, "Towards a (Semi-)Discourse of the Semi-Living," 97-112.
} 
To develop an ethics of the Semi-Living, three interrelated concerns should be acknowledged. First, this concept of ethics depends on whether or not the spectator of documentation experiences an other to whom she or he is able to respond and assumes or denies responsibility. Unlike the other who is a human neighbor or an animal that looks back with "its point of view regarding me," 79 the Semi-Living does not have a definitive point of view that either clarifies or contradicts its status as other for the spectator. Similarly, the Semi-Living is truly other in the sense that it/she/he does not have the "language" to call, request, or demand and is, therefore, undeterminable; as Derrida maintains, "[i]f the other were to share his reasons with us by explaining them to us . . . he wouldn't be other." 80 Second, making the other known involves an instrumental calculation rather than an undetermined responsibility to a wholly other; this is a political decision rather than an ethical response. ${ }^{81}$ The more one encounters Catts and Zurrs's writing and images, the more the Semi-Living begins to "share a type of homogeneity." ${ }^{22}$ By reducing it to the same, I respond only to the call of myself as other and, therefore, I am not being responsible at all. TC\&A's signature killing ritual for the live spectator resists this homogeneity, and is therefore closer to the Derridean ethical ideal, as the participant undertakes a singular event of engagement, a decision (to kill or not to kill) that cannot be taken up by anyone else, since to kill, she or he must touch the sculpture. As Derrida explains: "Just as no one can die in my place, no one can make a decision, what we call 'a decision,' in my place." 83 However, this is not as clear-cut as it might seem because the spectator is arguably responding to the call of the artists, rather than to the Semi-Living as other, who insist that the sculptures will have no one to care for them (for instance, to replace their nutrients and provide a sterile environment for them) following the installation. The third factor is that an informed and critical reading of ethics and politics in the biological arts is only possible by recognizing the complex relation between what bioartists do, what they (and other people) say they do, and the way in which their work is received. The iconic image of the fluorescent green rabbit in Eduardo Kac's GFP Bunny, for example, is manipulated using photo-editing software, ${ }^{84}$ even though its authenticity is rarely questioned in the academy. This begs the question: Does this knowledge that the document is manipulated affect the possibility for an ethical relation to emerge between the spectator and the animal?

The status of the document as a record of a live event is problematized in bioart, and therefore complicates an ethical engagement that occurs through documentation. ${ }^{85}$ Duff points out that "many artists intentionally play with this confusion (often in the form of art hoaxes)," while "cultural players and audiences coming to this work are often unaware of the implied irony of such artistic gestures." ${ }^{86}$ In this case, where one cannot be sure, as Philip Auslander argues, that the "connection between performance

\footnotetext{
${ }^{79}$ Jacques Derrida, “The Animal That Therefore I Am (More to Follow)," trans. David Wills, Critical Inquiry 28, no. 2 (2002): 369-418, quote on 380.

${ }^{80}$ Derrida, The Gift of Death, 57.

${ }^{81}$ Thurschwell, "Specters of Nietzsche," 1201.

${ }^{82}$ Derrida, The Gift of Death, 57.

${ }^{83}$ Ibid., 60.

${ }^{84}$ Ernestine Daubner, "Eduardo Kac and the Art of Spinning a Green Bunny," CIAC's Electronic Magazine 23 (2005), available at $h$ ttp://magazine.ciac.ca/archives/no_23/en/oeuvre4.htm (accessed 23 September 2013).

${ }^{85}$ For further discussion of the complexities of documentation in bioart, see Duff, "Going Viral," $36-44$.

${ }^{86}$ Ibid., 37.
} 
and document is ... ontological, with the event preceding and authorizing its documentation," ${ }^{87}$ we might turn toward attempts in performance studies to capture the relationship between the live event and documentation as a starting point for a more critically reflective engagement with the ethics of documentation in bioart. ${ }^{88}$ While performance scholars like Auslander, Amelia Jones, and Kathy O'Dell do not explicitly discuss the ethical implications of encountering art through documentation, their theoretical assertions about the production and reception of performance documents remind us that the condition of the document in bioart practice can be as contextual, sensual, and intersubjective as its performance-art counterpart.

The work of TC\&A prompts us to consider our relationship to life that exists beyond the body it originated from; to conceive of our ethical responsibility to "new" forms of biotechnological life; and to question the values that are placed on this life. Whether the reference to a Messiah of knowable characteristics encourages an ethical relation of responsibility to the absolute other or not, the spectrality of the messianic aesthetic, which deconstructs the ontological categories of presence and absence in its refusal to settle meaning, reinforces a reading of the Semi-Living as always "to come." While my focus on the messianic temporarily suspends other ways of reading TC\&A's work, it is important to acknowledge the possibility of a messianic aesthetic; this approach foregrounds the way in which TC\&A's images invite a moral, political, or ethical response. Such a move can help us to identify when the Semi-Living is reduced to a fixed and final meaning: either it is zoē or bios, living or nonliving, human or animal, for example. A reading that elevates one conceptualization of life above its apparent opposite- $z o \bar{e}$ over bios, living over nonliving, human over animal, and so on-in order to fix what is meant by the Semi-Living does not go through the ordeal of undecidability, which is arguably necessary for an "ethical" decision to be made.

An ethics of the Semi-Living demands an ethical interrogation of the biotechnological tools that are appropriated in artistic contexts, but it also asks us to reexamine the ethical engagements that we, as spectators, readers, participants, and commentators, bring to our encounters with bioart. We may not be able to fully account for these experiences, and, as Derrida argues, by "enter[ing] the medium of language," one risks losing the very singularity that allows her or him to assume responsibility to the other. ${ }^{89}$ However, the anticipated negative reception of Extra Ear from within the art institution is a reminder that any attempt to reflect on ethics in bioart is especially important when art comes face-to-face with censorship in the name of "ethics." To disregard the potential for a messianic aesthetic leaves unexamined the delicate play of meaning-making and affect on ethical relations. While questions of the ethics of bioart (or the ethics of artists who create it) are undoubtedly significant, the part that the spectator plays in the construction of the ethical relation is equally important. The possibility of a messianic without messianism in TC\&A's images recalls the indecision of the ethical moment in which we cannot anticipate the future and predetermine how to act ethically. The key question these images evoke for this particular spectator

\footnotetext{
${ }^{87}$ Philip Auslander, "The Performativity of Performance Documentation," PAJ: A Journal of Performance and Art 84 (2006): 1-10, quote on 1.

${ }^{88}$ Ibid.; Amelia Jones, "Presence' in Absentia: Experiencing Performance as Documentation," Art Journal 56 (1997): 11-18; Kathy O'Dell, "Displacing the Haptic: Performance Art, the Photographic Document, and the 1970s," Performance Research 2 (1997): 85-94.

${ }^{89}$ Derrida, The Gift of Death, 60.
} 
is: How does one make an ethical decision? Derrida offers a response when looking at the nature of the decision: "The only decision possible is the impossible decision. It is when it is not possible to know what must be done, when knowledge is not and cannot be determined that a decision is possible as such. Otherwise the decision is an application: one knows what has to be done, it's clear, there is no more decision possible." 90 This observation suggests that a decision is only possible if we look beyond those existing ethical frameworks that know how to act by applying preexisting rules. Perhaps, therefore, we should speak not of an ethics of the Semi-Living, but of an ethics without ethics of the Semi-Living that allows for indecision.

${ }^{90}$ Jacques Derrida, “Dialanguages," in Points . . Interviews, 1974-1994, 132-55, esp. 147-48 (emphasis in original). 